\title{
Daya Saing Bawang Merah di Provinsi Maluku dan Upaya Peningkatannya
}

\section{(Shallot Competitiveness in Maluku and Efforts to Improve It)}

\author{
Agung Budi Santoso*, Maryam Nurdin, Ismatul Hidayah
}

(Diterima Februari 2019/Disetujui April 2020)

\begin{abstract}
ABSTRAK
Bawang merah merupakan salah satu komoditas hortikultura yang memiliki tingkat kebutuhan yang tinggi. Di Maluku, kebutuhan bawang merah sebagian besar masih didatangkan dari luar wilayah, seperti Surabaya dan Makasar. Meskipun begitu, pemerintah terus melakukan pengembangan hortikultura, termasuk bawang merah melalui kawasan pertanian. Penelitian ini bertujuan untuk mengetahui daya saing bawang merah lokal yang terdiri atas keunggulan kompetitif dan komparatif dibandingkan dengan bawang merah yang berasal dari luar wilayah Maluku. Penelitian dilakukan pada tiga lokasi, yaitu Maluku Tenggara, Seram Bagian Barat, dan Maluku Tengah. Pengambilan data primer dilakukan dengan menggunakan kuesioner dengan teknik purposive sampling. Data primer tersebut selanjutnya diolah menggunakan Policy Analisis Matrix. Hasil penelitian menunjukkan bahwa bawang merah lokal memiliki keunggulan kompetitif dan komparatif dibandingkan dengan bawang merah dari luar Maluku. Kebijakan pemerintah secara efektif mampu meningkatkan insentif petani lokal. Akan tetapi, efektivitas kebijakan tersebut semakin menurun seiring dengan peningkatan produktivitasnya. Sistem usaha tani bawang merah yang memiliki produktivitas di atas 8 ton/ha lebih membutuhkan kebijakan output guna memberikan jaminan harga. Upaya peningkatan daya saing bawang merah dapat dilakukan dengan cara meningkatkan produktivitas dan membangun kelembagaan petani untuk mewujudkan pembangunan pertanian yang berkelanjutan.
\end{abstract}

Kata kunci: bawang merah, daya saing, kompetitif, dan komparatif

\section{ABSTRACT}

Shallot is one of horticultural commodities with a high demand. Majority of shallots in Maluku are bought from Surabaya and Makasar. However, the government continuously does horticultural development in the center of shallot production. The objective of this study was to analize the competitiveness and comparativeness of farming between shallots which are cultivated by local farmer and shallots which are imported. There were three locations of research i.e., Maluku Tenggara, Seram Bagian Barat, and Maluku Tengah. Primary data were collected by quessioner and used purposive sampling method. Primary data were analyzed using policy analysis matrix. The results showed that shallot farming in Maluku has comparative and competitive advantages compared with imported shallots. Agricultural government policy effectively increases local farmer insentive. However, it shows a decreasing trend while increasing productivity of shallot. Shallot farming having production higher than 8 ton/ha need output subsidy to give price guarantee. Effort to increase shallot competitiveness is conducted by increasing productivity and developing a farmer institution to make a sustainable agricultural development.

Keywords: shallot, competitiveness, competitive and comparative

\section{PENDAHULUAN}

Menurut Susanto \& Sirappa (2007), bawang merah termasuk salah satu komoditas dari 13 komoditas lain yang sesuai dan cocok untuk dikembangkan di Maluku. Berdasarkan data statistik, pada tahun 2015 produksi bawang merah di Maluku mencapai 543 ton. Jika diasumsikan kebutuhan bawang merah sebesar 2,49 $\mathrm{kg} / \mathrm{kapita} /$ tahun (Pusdatin 2015) maka Maluku membutuhkan bawang merah kurang lebih 4.199 ton/tahun. Kekurangan produksi bawang merah lokal dipenuhi dengan mendatangkan bawang merah dari Pulau Jawa dan Pulau Sulawesi.

Balai Pengkajian Teknologi Pertanian Maluku, Jl. Chr Soplanit Rumah Tiga, Ambon, Maluku 97233

* Penulis Korespondensi: Email: ardenasa@gmail.com
Rata-rata produktivitas bawang merah Maluku dari tahun 2011 hingga tahun 2015 adalah 2,95 ton/ha (BPS 2016). Angka tersebut jauh lebih rendah dibandingkan dengan produktivitas bawang merah nasional yang mencapai 10,22 ton/ha (Pusdatin 2017).

Beberapa upaya pemerintah telah dilakukan untuk meningkatkan produksi bawang merah, baik dengan cara ekstensifikasi maupun intensifikasi. Ekstensifikasi dilakukan dengan menetapkan beberapa wilayah di Maluku menjadi sentra produksi bawang merah yang tertuang dalam Kepmen No 472 tahun 2018. Proses intensifikasi juga dilakukan dengan melakukan pendampingan teknologi budi daya bawang merah oleh Balai Pengkajian Teknologi Pertanian Maluku. Selain pendampingan kawasan, varietas unggul baru juga dikembangkan sesuai dengan kondisi sumber daya di Maluku Tengah pada tahun 2018. 
Berbagai kendala, baik kendala teknis maupun kendala ekonomis, masih sering dijumpai dalam proses pengusahaan bawang merah. Kendala ekonomis yang banyak dijumpai oleh petani adalah fluktuasi harga dan biaya produksi yang tinggi (Yuniarti \& Afsari 2016). Biaya bawang merah yang didatangkan dalam skala yang besar lebih efisien dibandingkan dengan biaya produksi bawang merah lokal yang masih relatif lebih tinggi. Fluktuasi harga bawang merah sebenarnya dapat diatasi dengan melakukan penanaman bawang merah off-season (Purba 2014). Akan tetapi, pola tanam off season terkendala oleh masalah teknis yang paling banyak dijumpai, antara lain adalah penggunaan bibit yang berkualitas rendah, serangan OPT, dan teknik budi daya.

Masalah teknis budi daya dapat diatasi dengan upaya diseminasi teknologi budi daya oleh pemerintah daerah ataupun instansi penyedia teknologi. Akan tetapi, berbeda dari permasalahan ekonomis mengingat pengembangan bawang merah pada saat ini masih terus didampingi dan disubsidi oleh pemerintah daerah, padahal kebijakan subsidi memengaruhi daya saing komoditas terhadap komoditas yang masuk di Maluku.

Berdasarkan latar belakang tersebut, pengkajian daya saing bawang merah lokal terhadap bawang merah yang didatangkan dari luar Maluku perlu dilakukan untuk membantu pemerintah daerah memahami posisi bawang lokal agar tetap memberikan kontribusi pendapatan terhadap petani lokal tanpa harus mengurangi atau mencegah datangnya bawang merah dari daerah lain. Selain itu, kajian ini dapat mengevaluasi kebijakan pemerintah daerah pada saat ini dengan mengetahui berapa besar manfaat kebijakan yang telah dilakukan bagi petani lokal.

Penelitian tentang keunggulan bawang merah lokal dibandingkan dengan bawang merah impor telah dilakukan di berbagai tempat. Aldila et al. (2017) melakukan penelitian di tiga sentra produksi bawang merah, yaitu Brebes, Tegal, dan Cirebon. Bawang merah di ketiga tempat tersebut menguntungkan secara finansial, namun tidak menguntungkan secara ekonomi karena bergantung pada kebijakan pemerintah. Penelitian yang dilakukan oleh Suharyani et al. (2014) di Brebes dan Rahmadona et al. (2018) di Majalengka menyatakan bahwa bawang merah memiliki keunggulan kompetitif, namun tidak unggul secara komparatif. Sutiarso (2012) melakukan kajian yang sama di Probolinggo dan menyimpulkan bahwa bawang merah di daerah tersebut memiliki keunggulan, baik kompetitif maupun komparatif. Kenaikan harga input seperti benih dan pupuk, produktivitas, dan harga output memengaruhi keunggulan kompetitif. Sementara itu, keunggulan komparatif lebih sensitif terhadap produktivitas (Nurdi \& Baladina 2017).

Berdasarkan permasalahan yang diutarakan di atas, penelitian ini bertujuan untuk mengetahui keunggulan kompetitif dan komparatif bawang merah lokal terhadap bawang merah yang didatangkan dari luar Maluku. Hasil penelitian diharapkan dapat membantu pemerintah mengembangkan komoditas bawang merah sehingga memiliki daya saing yang lebih tinggi terhadap bawang merah dari luar Maluku.

\section{METODE PENELITIAN}

Penelitian ini dilakukan di tiga tempat yang menjadi sentra produksi bawang merah di Maluku, yakni Maluku Tenggara, Seram Bagian Barat, dan Maluku Tengah. Penentuan lokasi ditentukan dengan tehnik purposive dengan pertimbangan bahwa ketiga tempat tersebut telah mendapatkan pendampingan teknologi kawasan hortikultura. Pada tiap lokasi diwawancarai sebanyak 30 responden petani. Penentuan responden dilakukan secara simple random. Penentuan ini dilakukan karena kondisi petani dari segi struktur pembiayaan dan sistem pengolahan memiliki sifat yang homogen. Hampir semua petani menggunakan dosis pupuk, obat-obatan, dan sistem pengolahan yang sama karena mendapatkan bantuan dari pemerintah.

Pelaksanaan survei dilakukan pada Bulan AgustusNovember 2018. Pengambilan data dilakukan dengan menggunakan kuesioner. Selain petani, pengambilan data primer juga dilakukan pada distributor pupuk, distributor bawang merah, dan pedagang bawang merah di pasar setempat. Perolehan data yang dimaksud adalah data paritas harga pupuk dan bawang merah yang berasal dari luar Maluku.

Data kemudian diolah dengan menggunakan metode Policy Analysis Matrix (PAM). Metode ini dipilih karena mampu menggambarkan keunggulan kompetitif dan keunggulan komparatif komoditas di suatu daerah, dalam hal ini pembandingan antara bawang merah lokal dan bawang merah dari luar Maluku. Selain itu, PAM biasanya digunakan untuk mengetahui dampak kebijakan pemerintah pada suatu komoditas.

Komponen PAM terdiri atas pendapatan, input tradable, biaya faktor domestik, dan keuntungan (Pearson \& Gotsch 2004). Baris pertama pada Tabel PAM menggambarkan kondisi penerimaan dan pembiayaan usaha tani bawang merah dengan harga privat atau harga yang real diterima oleh petani. Pada baris ini diperhitungkan usaha tani dengan harga aktual, seperti perolehan benih, pupuk, pestisida, dan lain-lain. Baris kedua menggambarkan kondisi usaha tani dengan harga sosial. Harga sosial yang dimaksud adalah harga tanpa adanya intervensi pemerintah, seperti subsidi atau pajak. Jika pada harga privat petani memperoleh subsidi benih dan pupuk maka perhitungan pada baris ini harga yang digunakan adalah harga tanpa subsidi. Baris ketiga merupakan divergensi selisih antara baris pertama dan baris kedua. Divergensi ini mencerminkan sejauh mana pemerintah melakukan kebijakan atas suatu komoditas.

Tingkat daya saing komoditas, baik kompetitif maupun komparatif, ditentukan oleh beberapa indikator dengan menggunakan perhitungan pada persamaan (1) sampai dengan (7). Adapun makna A, B, C, D, E, F, G, H, I, J, K, dan L dapat dilihat pada Tabel 1. 
Tabel 1 Perhitungan Policy Analysis Matrix

\begin{tabular}{lcccc}
\hline & Penerimaan & $\begin{array}{c}\text { Biaya input } \\
\text { tradable }\end{array}$ & $\begin{array}{c}\text { Biaya factor } \\
\text { domestik }\end{array}$ & Keuntungan \\
\hline Privat & $\mathrm{A}$ & $\mathrm{B}$ & $\mathrm{C}$ & $\mathrm{D}$ \\
Sosial & $\mathrm{E}$ & $\mathrm{F}$ & $\mathrm{G}$ & $\mathrm{H}$ \\
Divergensi & $\mathrm{I}$ & $\mathrm{J}$ & $\mathrm{K}$ & $\mathrm{L}$ \\
\hline
\end{tabular}

Sumber: (Monke \& Pearson 1989).

Keterangan: $\quad \mathrm{A}=$ Penerimaan individu (produksi dikalikan harga pasar), $\mathrm{B}=$ Input tradable dikalikan harga pasar, $\mathrm{C}=$ Input faktor domestik dikalikan harga pasar, $\mathrm{D}=$ Private profits atau pendapatan individu $\mathrm{A}-(\mathrm{B}+\mathrm{C}), \mathrm{E}=$ Penerimaan sosial (produksi dikalikan harga sosial), $\mathrm{F}=$ Input tradable dikalikan harga sosial, $\mathrm{G}=$ Input faktor domestik dikalikan harga sosial, $\mathrm{H}=$ Social profit atau pendapatan sosial $(\mathrm{E}-(\mathrm{F}+\mathrm{G}), \mathrm{I}=$ Output transfer $(\mathrm{A}-\mathrm{E}), \mathrm{J}=$ Input transfer atau transfer input tradable $(\mathrm{B}-\mathrm{F}), \mathrm{K}=$ Faktor domestik transfer (C-G), dan $\mathrm{L}=$ Net policy transfer atau transfer bersih $(\mathrm{D}-\mathrm{H})$.

NPCO (Nominal Protection Coefficient Output) =

$\mathrm{A} / \mathrm{E}$.

$\mathrm{NPCl}$ (Nominal Protection Coefficient Input) $=\mathrm{B} / \mathrm{F} \ldots . .(2)$

EPC (Effective Protection Coefficient $)=(A-B) /(E-F) .(3)$

$\mathrm{PC}($ Profitability Coefficient $)=\mathrm{D} / \mathrm{H} \ldots \ldots \ldots \ldots \ldots \ldots \ldots . . . . . . . .4)$

$\mathrm{PCR}($ Private Cost Ratio) $=\mathrm{C} /(\mathrm{A}-\mathrm{B})$.

DCR (Domestic Cost Ratio) $=\mathrm{G} /(\mathrm{E}-\mathrm{F})$.

SRP (Subsidy Ratio to produce) $=\mathrm{L} / \mathrm{E}$

Adapun keterangan indikator yang digunakan pada PAM ini adalah sebagai berikut:

- NPCO > 1, maka usaha tani bawang merah menerima proteksi

NPCO $<1$, maka usaha tani bawang merah tidak menerima proteksi

- $\mathrm{NPCl}>1$, maka penggunaan harga aktual domestik input tradable $>$ harga nasional. $\mathrm{NPCl}<1$, maka penggunaan harga aktual domestik input tradable < harga nasional.

- $\quad P C>1$, maka intervensi pemerintah membuat profit petani $>$ konsumen

$\mathrm{PC}<1$, maka intervensi pemerintah membuat profit petani < konsumen

- $E P C>1$, kebijakan pemerintah bersifat protektif EPC < 1, kebijakan pemerintah bersifat tidak protektif

- SRP bernilai positif, maka distorsi kebijakan dapat meningkatkan keuntungan. SRP bernilai negatif, maka distorsi kebijakan dapat menurunkan keuntungan.

- PCR, semakin kecil nilainya maka semakin berdaya saing (kompetitif)

- DCR, semakin kecil nilainya maka semakin berdaya saing (komparatif)

\section{HASIL DAN PEMBAHASAN}

\section{Produksi dan Penerimaan Usaha Tani Bawang Merah}

Produktivitas bawang merah di Maluku Tenggara berkisar antara 5-6 ton/ha, sedangkan di Seram bagian Barat dan Maluku Tengah memiliki produktivitas 5-8 ton. Perbedaan ini dipengaruhi oleh kondisi iklim dan ketersediaan air di daerah masing-masing. Pola tanam bawang merah di ketiga lokasi penelitian tidak berbeda, yakni hanya menanam sekali dalam satu tahun dengan alasan menyesuaikan dengan keadaan cuaca.

Harga jual bawang merah di tingkat produsen adalah Rp20.000/kg yang selanjutnya didistribusikan ke pasar dengan harga Rp25.000/kg untuk wilayah Maluku Tenggara. Proses penjualan dilakukan dengan menjual langsung di pasar karena Maluku Tenggara dan Kota Tual hanya memiliki jumlah penduduk 10\% dari total populasi di Maluku (BPS 2016), penjualan bawang terkadang dilanjutkan ke daerah terdekat, seperti Dobo, Kaimana, dan Timika. Proses penjualan yang dilakukan secara indi-vidu atau pribadi membuat tingkat efisiensi distribusi pemasarannya masih rendah.

Maluku Tengah dan Seram Bagian Barat yang memiliki wilayah dalam satu daratan, memiliki harga yang berkisar antara Rp18.000-25.000. Proses penjualan dilakukan oleh pengepul yang datang pada saat panen dan mendistribusikannya ke pasar. Harga pada tingkat konsumen ditentukan berdasarkan kualitas bawang sehingga tidak ada perbedaan perlakuan antara bawang lokal dengan bawang yang didatangkan dari luar Maluku. Bawang merah dengan kualitas terbaik bisa mencapai Rp30.000/kg.

Berdasarkan informasi perkembangan harga dari berbagai pasar, seperti Surabaya, Makassar, dan Maluku, terlihat bahwa selisih harga dari ketiga kota tersebut cukuplah besar. Perbedaan harga mencapai Rp24.500 bahkan harga bawang merah mencapai Rp30.000 di Kota Tual (Gambar 1). Hal ini membuat distribusi bawang merah dari luar Maluku dapat lebih efisien dengan kuantitas yang besar karena melalui transportasi laut. Faktor lainnya adalah tidak ada hambatan komoditas dan jarak antara pasar dan pelabuhan yang dekat karena Maluku daerah kepulauan membuat biaya transportasi menjadi murah. Hal ini yang menjadikan harga sosial bawang merah tidak berbeda dari harga privat. Harga sosial berkisar antara Rp18.500 20.000/kg. Menurut Monke \& Pearson (1989), harga sosial merupakan biaya yang dikeluarkan oleh konsumen luar untuk membeli dari petani lokal, atau biaya yang dikeluarkan oleh petani luar untuk mendatangkan atau memasukkan komoditas ke konsumen lokal.

Kondisi penerimaan, keuntungan, dan biaya yang dikeluarkan oleh petani lokal tergambar pada Tabel 2. Komponen biaya meliputi biaya benih, pupuk, tenaga kerja, dan sewa lahan. Terlihat bahwa tenaga kerja memiliki proporsi tertinggi pada komponen biaya, yakni 
sekitar $48 \%$. Hal ini menandakan bahwa usaha tani bawang merah menyerap banyak tenaga kerja dengan melibatkan anggota keluarga dan petani dari desa yang sama.

Proporsi terbesar kedua setelah tenaga kerja adalah benih, sekitar $40 \%$. Benih yang digunakan pada saat ini adalah benih umbi yang saat ini disubsidi oleh pemerintah daerah dengan mendatangkan dari daerah luar.

B/C ratio dalam Tabel 2 tersebut senilai 0,94 yang menandakan setiap Rp1 yang dikeluarkan oleh petani dalam usaha tani bawang merah, memberikan keuntungan sejumlah Rp0,94 atau memiliki tingkat pengembalian $94 \%$. Hal ini menandakan bahwa usaha tani bawang merah layak diusahakan, terlebih lagi komponen biaya tenaga kerja merupakan komponen yang melibatkan tenaga kerja keluarga sehingga penerimaan tunai akan lebih besar.

Break Even Point (BEP) merupakan harga minimal yang diterima oleh petani untuk menutupi biaya produksi. Tabel 2 menunjukkan bahwa BEP usaha tani bawang merah adalah senilai $\mathrm{Rp}$ 10.326. Harga ini cukup kompetitif terhadap bawang merah yang didatangkan dari luar dengan nilai yang mencapai Rp18.500-30.000. Akan tetapi, pada saat produktivitas hanya mencapai 4 ton/ha, BEP meningkat menjadi Rp15.450. Hal ini disebabkan karena besar nilai BEP berhubungan terbalik dengan jumlah produksi.

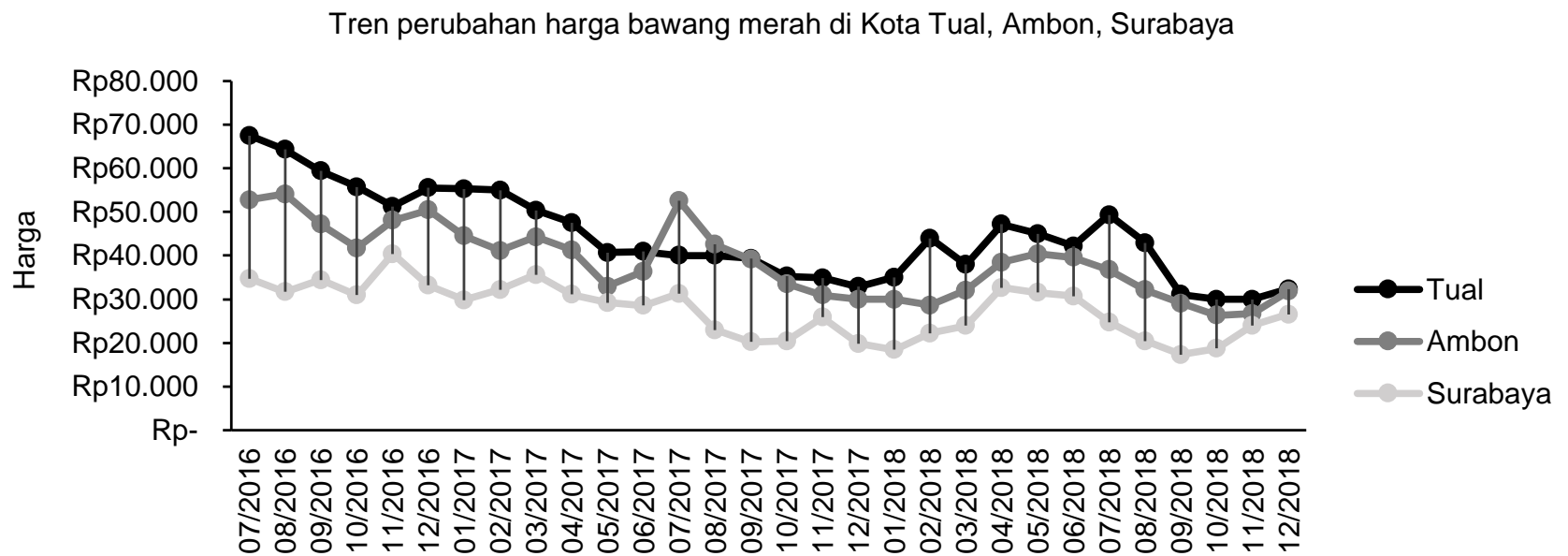

Periode

Sumber: Bank Indonesia (https://hargapangan.id/ diakses 31 Januari 2019). Gambar 1 Perkembangan harga bawang merah pada tahun 2016-2018.

Tabel 2 Usaha tani bawang merah di Tual, Ambon, dan Seram bagian Barat

\begin{tabular}{|c|c|c|c|c|}
\hline Komponen & Satuan & Kuantitas & Harga satuan (Rp) & Jumlah (Rp) \\
\hline \multicolumn{5}{|l|}{ Biaya } \\
\hline Benih & $\mathrm{kg}$ & 1.250 & 20.000 & 25.000 .000 \\
\hline \multicolumn{5}{|l|}{ Pupuk } \\
\hline \multicolumn{5}{|l|}{ a. Pupuk kimia } \\
\hline - Urea & $\mathrm{kg}$ & 200 & 1.800 & 360.000 \\
\hline - TSP/SP-36 & $\mathrm{kg}$ & 100 & 2.000 & 200.000 \\
\hline$-\mathrm{KCl}$ & $\mathrm{kg}$ & 200 & 9.000 & 1.800 .000 \\
\hline$-\mathrm{ZA}$ & $\mathrm{kg}$ & 100 & 1.400 & 140.000 \\
\hline \multicolumn{5}{|l|}{ - NPK } \\
\hline b. Pupuk lain & $\mathrm{kg}$ & 2.000 & 500 & 1.000 .000 \\
\hline c. Pestisida & paket & 1 & 1.460 .000 & 1.460 .000 \\
\hline d. Herbisida & paket & 0 & & - \\
\hline Tenaga Kerja & & 200 & 150.000 & 30.000 .000 \\
\hline Sewa Lahan & & 1 & 2.000 .000 & 2.000 .000 \\
\hline Total Biaya & & & & 61.960 .000 \\
\hline \multicolumn{5}{|l|}{ Penerimaan } \\
\hline Produksi & $\mathrm{kg}$ & 6.000 & 20.000 & 120.000 .000 \\
\hline Keuntungan & & & & 58.040 .000 \\
\hline $\mathrm{B} / \mathrm{C}$ ratio & & & & 0,94 \\
\hline $\mathrm{R} / \mathrm{C}$ ratio & & & & 1,94 \\
\hline BEP & $\mathrm{Rp}$ & & 10.326 & \\
\hline
\end{tabular}




\section{Keuntungan Private dan Sosial Usaha Tani Bawang Merah}

Berdasarkan informasi dan data yang dihimpun, Tabel PAM disusun berdasarkan tiga lokasi penelitian. Jika dilihat dari Tabel 3, terlihat bahwa semua lokasi usaha tani bawang merah memiliki keuntungan, baik secara privat maupun sosial. Hal ini menandakan bahwa secara finansial penerimaan usaha tani masih lebih besar dibandingkan dengan biaya usaha tani sehingga usaha tani bawang merah dapat dikatakan menguntungkan bagi petani lokal.

Keuntungan privat dan sosial yang diterima petani di ketiga lokasi tersebut berbeda-beda. Pendapatan privat tertinggi diperoleh petani lokal di Maluku Tenggara, kemudian diikuti oleh petani lokal di Seram bagian Barat dan Maluku Tengah. Keuntungan privat petani lokal di Maluku Tenggara jauh lebih tinggi dibandingkan dengan petani lokal di Seram bagian Barat dan Maluku Tengah, yaitu selisihnya mencapai 20 juta. Akan tetapi, karena produktivitas bawang merah di Maluku Tenggara relatif lebih rendah (5 ton/ha) dibandingkan dengan produktivitas di Seram Bagian Barat (7 ton/ha) maka penerimaan usaha tani di Maluku Tenggara lebih kecil yang berdampak pada pendapatan sosial dari kedua tempat tersebut hanya berselisih 2 juta.

Petani lokal Maluku Tenggara menggantungkan sebagian besar sumber input dari pemerintah dan tidak menambah pestisida atau pupuk tambahan lainnya. Hal ini terlihat dari besarnya selisih antara biaya tradable input private dengan sosialnya yang mencapai Rp49.940.000. Keadaan ini berbeda dari keadaan petani lokal di Seram bagian Barat. Petani lokal di Seram bagian Barat, selain menerima subsidi pupuk dan benih, mereka juga mengeluarkan biaya untuk mendapatkan pestisida dan pupuk tambahan, seperti pupuk cair dan kandungan mikro untuk meningkatkan produktivitasnya.

Besarnya selisih antara biaya privat dan sosial pada bagian tradable input membuat profit juga memiliki kesenjangan yang tinggi di Maluku Tenggara. Petani menerima profit Rp73.523/ha dengan kondisi menerima subsidi dan bantuan pemerintah. Jika subsidi tersebut dilepas, keuntungan usaha tani hanya mencapai Rp22.567.400/ha

Komponen biaya domestic factors tidak mengalami perbedaan yang tinggi. Hal ini disebabkan karena petani menggunakan komponen biaya dari tenaga kerja sendiri dan pemerintah tidak melakukan intervensi terhadap penggunaan tenaga kerja, sewa lahan, dan modal.

\section{Keunggulan Kompetitif dan Komparatif dan Pengaruh Kebijakan Pemerintah}

Indikator yang digunakan dalam Policy Analysis Matrix (PAM) untuk mengkaji kebijakan pemerintah dalam mengem-bangkan komoditas bawang merah dapat dilihat pada Tabel 4. Terdapat tujuh indikator yang digunakan, yakni Nominal Protection Coefficient on Ouput (NPCO), Nominal Protection Coefficient on Input (NPCl), Private Cost Ratio (PCR), Efective Protection Coefficient (EPC), Profiability Coefficient (PC), Subsidy Ratio to Producers (SRP), dan Domestic Resource Cost (DRC).

Tabel 3 Kondisi pendapatan dan keragaan biaya usaha tani bawang merah per ha

\begin{tabular}{|c|c|c|c|c|c|c|c|}
\hline & Penerimaan & Tradable & \multicolumn{4}{|c|}{ Domestic factors } & \multirow[t]{2}{*}{ Profit } \\
\hline & & Input & Tenaga kerja & Lahan & Biaya modal & Total & \\
\hline Seram Bagian Barat & & & & & & & \\
\hline Private & 120.000 .000 & 29.960 .000 & 30.000 .000 & 2.000 .000 & 364.470 & 32.364 .470 & 57.675 .530 \\
\hline Social & 114.600 .000 & 62.030 .000 & 30.000 .000 & 2.000 .000 & 367.480 & 32.367 .480 & 20.202 .520 \\
\hline Divergences & 5.400 .000 & -32.070 .000 & 0 & 0 & -3.010 & -3.010 & 37.473 .010 \\
\hline \multicolumn{8}{|l|}{ Maluku Tengah } \\
\hline Private & 99.000 .000 & 5.400 .000 & 34.200 .000 & 2.000 .000 & 29.750 & 36.229 .750 & 57.370 .250 \\
\hline Social & 95.7 & 40.816 .100 & 34.200 .000 & 2.000 .000 & 51.180 & 36.251 .180 & 18.632 .720 \\
\hline Divergences & 3.300 .000 & -35.416 .100 & 0 & 0 & -21.430 & -21.430 & 38.737 .530 \\
\hline \multicolumn{8}{|l|}{ Maluku Tenggara } \\
\hline Private & 100.000 .000 & 1.160 .000 & 20.000 .000 & 3.000 .000 & 2.316 .5 & 25.316 .500 & 73.523 .500 \\
\hline Social & 99.000 .000 & 51.100 .000 & 20.000 .000 & 3.000 .000 & 2.332 .600 & 25.332 .600 & 22.567 .400 \\
\hline Divergences & 1.000 .000 & -49.940 .000 & 0 & 0 & -16.100 & -16.100 & 50.956 .100 \\
\hline
\end{tabular}

Tabel 4 Indikator Policy Analysis Matrix (PAM) dalam usaha tani bawang merah di lokasi penelitian

\begin{tabular}{lccc}
\hline & RATIOS & & Lokasi \\
\cline { 2 - 4 } & SBB & Malteng & Malra \\
\hline NPCO [A/E] & 1,05 & 1,03 & 1,01 \\
NPCI [B/F] & 0,48 & 0,13 & 0,02 \\
EPC [(A-B)/(E-F)] & 1,71 & 1,71 & 2,06 \\
PCR [C/(A-B)] & 0,36 & 0,39 & 0,26 \\
DRC [G/(E-F)] & 0,62 & 0,66 & 0,53 \\
PC [D/H) & 2,85 & 3,08 & 3,26 \\
SRP [L/E] & 0,33 & 0,40 & 0,51 \\
\hline
\end{tabular}

Keterangan: SBB = Seram Bagian Barat, Malteng = Maluku Tengah, dan Malra = Maluku Tenggara. 
NPCO adalah rasio antara harga pasar domestik sebuah produk dan harga paritasnya. NPCO pada Tabel 4 memiliki nilai $=1$. Hal ini menandakan bahwa pasar mengalami netral dan bebas intervensi dari pemerintah. Berbeda halnya dari NPCl, pemerintah melakukan kebijakan intervensi pada perolehan input sistem usaha tani bawang merah. Hal ini ditandai dengan nilai NPCI di bawah 1. Input yang dimaksud di sini adalah tradable input yang terdiri atas benih, pupuk, dan pestisida. Maluku Tenggara merupakan wilayah yang memiliki intervensi dalam pengadaan input paling tinggi dibandingkan dengan wilayah lainnya.

Effective protection coefficient (EPC) adalah ratio nilai tambah pada tingkat harga privat dan sosialnya. Jika NPCO dan NPCl memperhitungkan distorsi kebijakan pemerintah pada output dan input secara parsial maka EPC menggabungkan keduanya. Kesemua lokasi memperoleh nilai EPC di atas 1 . Hal ini menandakan bahwa usaha tani bawang merah di semua lokasi penelitian memiliki proteksi, yakni intervensi pemerintah dalam hal pengadaan bantuan dan subsidi input. Proteksi tersebut yang menimbulkan nilai keuntungan private atau keuntungan yang diterima petani secara riil lebih besar dibandingkan dengan keuntungan yang seharusnya diperolehnya.

Private cost ratio (PCR) merupakan rasio antara biaya domestik dan nilai tambah pada harga privat (selisih antara penerimaan dengan biaya input tradable). Semakin tinggi nilai PCR maka usaha tani dikatakan tidak memiliki nilai daya saing. Hal ini disebabkan karena tingginya biaya faktor domestik yang dikeluarkan tidak dibarengi oleh peningkatan pendapatan. Tabel 2 menunjukkan bahwa semua lokasi penelitian memperoleh nilai PCR di bawah 1 sehingga dapat dikatakan bahwa usaha tani bawang merah memiliki keunggulan kompetitif.

Domestic resource cost (DRC) adalah rasio antara biaya sumber daya domestik yang dinilai pada tingkat harga sosial atas nilai tambah sosialnya. Jika PCR menerangkan pada harga privat, maka DRC menerangkan daya saing pada harga sosial. Nilai DRC pada Tabel 4 di atas berada di bawah 1 sehingga dapat dikatakan bahwa usaha tani bawang merah di Maluku memiliki keunggulan ekonomi atau keunggulan komparatif.

Profitability coefficient (PC) merupakan rasio antara keuntungan privat dan keuntungan sosial. Jika nilai PC sama dengan 1 berarti tidak ada perbedaan antara keuntungan privat dan keuntungan sosial. Jika nilai PC $>1$, maka keuntungan privat lebih besar dibandingkan dengan keuntungan sosial (karena petani menerima subsidi). Tabel 4 menjelaskan bahwa nilai PC $>1$ di semua lokasi penelitian. Hal ini mencerminkan bahwa keuntungan privat pada usaha tani tersebut lebih tinggi dibandingkan dengan keuntungan sosial.

Pengaruh intervensi pemerintah pada pendapatan petani lokal juga dapat dilihat dari subsidy ratio to producers (SRP). SRP menunjukkan seberapa besar pendapatan meningkat atau menurun yang diakibatkan oleh transfer kebijakan pemerintah. Tabel 4 menjelaskan bahwa nilai SRP bernilai positif sehingga dapat diartikan bahwa kebijakan pemerintah mampu meningkatkan pendapatan.

\section{Produktivitas dan Daya Saing Bawang Merah}

Tingkat produktivitas bawang merah yang beragam di Maluku dengan angka minimal 4 ton/ha dan bisa mencapai 8 ton/ha menghasilkan nilai daya saing bawang merah yang berbeda, baik secara kompetitif maupun komparatif. Tabel 5 menjelaskan tentang kondisi produktivitas yang berbeda dan pengaruhnya pada keunggulan kompetitif dan kom-paratif bawang merah.

Berdasarkan nilai NPCO, NPCI, dan EPC dapat dilihat bahwa pemerintah melakukan intervensi dalam pengadaan input usaha tani bawang merah. Intervensi input yang dilakukan oleh pemerintah meningkatkan insentif petani lokal pada kedua kondisi tersebut. Akan tetapi, insentif yang diterima oleh petani dengan produktivitas 4 ton/ha lebih tinggi dibandingkan dengan petani yang mendapatkan produktivitas 8 ton/ha. Hal ini terlihat dari nilai EPC pada kondisi $A$ lebih besar $(2,81)$ dibandingkan dengan pada kondisi $B(1,48)$.

Berdasarkan nilai PCR, terlihat bahwa kedua kondisi tersebut memiliki keunggulan kompetitif karena memiliki nilai di bawah 1. Akan tetapi, kondisi B jauh lebih berdaya saing dibandingkan dengan kondisi $A$. Hal tersebut juga terlihat pada nilai DRC yang mencerminkan keunggulan komparatif. Meskipun kedua kondisi tersebut memiliki nilai di bawah 1, namun pada kondisi $A$ bernilai 0,9 jauh lebih besar dibandingkan dengan kondisi $B(0,24)$. Hal ini menandakan bahwa kondisi $A$ memiliki sistem produksi yang kurang efektif karena keuntungan yang diperoleh pada sistem produksi tersebut hanya cukup untuk menutupi biaya. Hal ini memberikan pengertian bahwa jika suatu saat pemerintah mencabut susbsidi benih dan pupuk, perlu mempertimbangkan tingkat produktivitas usaha tani bawang merah. Karena jika pemerintah mencabut subsidi pada kondisi $A$, petani akan menanggung biaya sosial sehingga keuntungan yang diperoleh hanya cukup memenuhi biaya sosial tersebut.

\section{Upaya Peningkatan Daya Saing Bawang Merah di Maluku}

Upaya peningkatan daya saing bawang merah di Maluku dapat dilakukan dengan cara meningkatkan

Tabel 5 Kondisi PAM pada kondisi produktivitas yang berbeda

\begin{tabular}{lrr}
\hline \multirow{2}{*}{ Ratios } & \multicolumn{2}{c}{ Produktivitas } \\
\cline { 2 - 3 } & $\begin{array}{c}\mathrm{A} \\
\text { 4 ton/ha }\end{array}$ & $\begin{array}{c}\mathrm{B} \\
8 \text { ton/ha }\end{array}$ \\
\hline $\mathrm{NPCO}[\mathrm{A} / \mathrm{E}]$ & 1,01 & 1,01 \\
$\mathrm{NPCl}[\mathrm{B} / \mathrm{F}]$ & 0,02 & 0,02 \\
$\mathrm{EPC}[(\mathrm{A}-\mathrm{B}) /(\mathrm{E}-\mathrm{F})]$ & 2,81 & 1,48 \\
$\mathrm{PCR}[\mathrm{C} /(\mathrm{A}-\mathrm{B})]$ & 0,32 & 0,16 \\
$\mathrm{DRC}[\mathrm{G} /(\mathrm{E}-\mathrm{F})]$ & 0,90 & 0,24 \\
$\mathrm{PC}[\mathrm{D} / \mathrm{H})$ & 19,34 & 1,63 \\
SRP $[\mathrm{L} / \mathrm{E}]$ & 0,64 & 0,33 \\
\hline
\end{tabular}


produktivitas. Produktivitas lahan akan meningkatkan efisiensi sumber daya domestik (lahan, tenaga kerja, dan modal) dengan penggunaan biaya input tradable yang relatif sama. Peningkatan produktivitas dapat dilakukan dengan pemanfaatan benih unggul dan penggunaan pupuk secara tepat dosis dan waktu. Hal ini sejalan dengan upaya BPTP Maluku dengan melakukan diseminasi teknologi melalui demplot dan pendampingan kawasan. Penggunaan pupuk sesuai dengan rekomendasi yang dilakukan dengan pengujian lahan sebelumnya. Selain itu, pengembangan benih unggul baru yang telah diadaptasikan dengan kondisi Maluku perlu diteruskan karena terbukti menghasilkan produktivitas yang lebih tinggi (Santoso et al. 2019).

Akan tetapi, upaya peningkatan produktivitas lahan tersebut sebaiknya diiringi dengan pembangunan dan sarana pemasaran sehingga panen yang dihasilkan petani lokal terserap sepenuhnya oleh pasar. Kondisi bawang merah yang tidak tahan lama dalam area penyimpanan akan menyebabkan fluktuasi harga yang begitu cepat terhadap kondisi stok. Meskipun terdapat beberapa rekomendasi teknik penyimpanan komoditas hortikultura, keadaan tersebut tetap tidak bisa menjamin ketahanan komoditas tersebut dalam jangka panjang (Samad 2006).

Salah satu upaya yang dapat dilakukan untuk memenuhi kebutuhan pemasaran adalah dengan memperkuat kelembagaan petani (Tsurayya \& Kartika 2015). Menurut Suradisastra (2008), kelembagaan dapat meningkatkan perhatian dan motivasi berusaha tani karena melibatkan norma. perilaku dan kondisi hubungan sosial sesama petani. Hal ini menyebabkan posisi petani sebagai suatu lembaga produksi pertanian akan semakin kuat. Pemerintah sebaiknya dapat memanfaatkan kelompok tani untuk mengakomodir kebijakan pemerintah baik subsidi input maupun subsidi output. Kelembagaan berupa toko tani yang dikelola oleh kelompok tani untuk melakukan kegiatan operasional distribusi benih dan pupuk, menyerap produk petani, dan memasarkan hasil di daerah luar.

Melalui kelembagaan ini, pemerintah dapat mengurangi subsidi input secara bertahap sekaligus mewadahi operasional pemasaran petani bawang, terutama dalam hal biaya distribusi di daerah luar, seperti Kaimana, Dobo, dan Timika. Melalui kelembagaan tersebut diharapkan penjualan dapat dilakukan dalam bentuk partai besar untuk meningkatkan keuntungan dan daya saing produk.
Selain kelembagaan yang mengatur subsidi input dan output, kelembagaan yang tidak kalah pentingnya adalah penangkar benih. Kondisi pada saat ini adalah petani bergantung pada bantuan pemerintah dalam pengadaan benih dari daerah luar karena belum terdapat penangkar benih mandiri. Padahal, komponen pembelian benih memiliki proporsi terbesar kedua setelah tenaga kerja (Tabel 2). Penguatan kelembagaan penyedia benih juga perlu dilakukan mengingat kondisi geografis Maluku berbentuk kepulauan sehingga ongkos pengiriman benih menjadi mahal. Ketersediaan penengkar benih mandiri akan menjamin kawasan bawang merah berkelanjutan yang dapat menunjang tidak hanya produktivitas melainkan efisiensi biaya usaha tani bawang merah.

Upaya lain yang dapat dilakukan untuk meningkatkan daya saing bawang merah adalah dengan cara pengaturan jadwal tanam untuk menyesuaikan ketersediaan stok bawang merah yang berasal dari luar, khususnya Pulau Jawa. Upaya ini dilakukan untuk mencegah kelebihan stok yang menyebabkan harga rendah sehingga dapat merugikan petani. Jadwal tanam petani lokal disesuaikan dengan musim panen dan cuaca, baik daerah asal maupun kondisi setempat.

Secara keseluruhan, harga bawang merah mengalami penurunan sejak tahun 2016, baik di Surabaya, Ambon, dan Maluku Tenggara (Gambar 1). Jika harga tersebut dikelompokkan ke dalam triwulan maka terlihat kecenderungan harga bawang merah akan naik pada triwulan ketiga, seperti yang terlihat pada Tabel 6.

Pada Tabel 6 terlihat bahwa triwulan 2 dan triwulan 4 memiliki harga yang relatif tinggi di Surabaya. Sementara itu, harga bawang merah di Tual dan Ambon relatif tinggi pada triwulan 3 dan triwulan 1 . Sementara itu, apabila menghitung selisih harga, terjadi selisih harga lebih dari Rp20.000 di triwulan 3. Hal ini menunjukkan bahwa produksi di triwulan 3 dan triwulan 1 lebih menjamin harga.

\section{KESIMPULAN}

Usaha tani bawang merah di Maluku memiliki keunggulan kompetitif dan komparatif. Budi daya bawang merah di ketiga tempat lokasi penelitian menunjukkan keuntungan, baik secara private maupun sosial. Kebijakan pemerintah dalam mengembangkan bawang merah melalui subsidi dan bantuan input dapat meningkatkan insentif petani lokal. Pendapatan privat

Tabel 6 Perkembangan harga jual bawang merah per triwulan pada tahun 2016-2018

\begin{tabular}{lccc}
\hline & Surabaya & Ambon & Tual \\
\cline { 2 - 4 } & & $(\mathrm{Rp})$ & 46.242 \\
& & 36.758 & 43.900 \\
Triwulan 1 & 27.050 & 38.167 & 48.206 \\
Triwulan 2 & 30.625 & 42.889 & 39.761 \\
Triwulan 3 & 26.422 & 35.506 & \\
\hline
\end{tabular}

Sumber: Bank Indonesia (https://hargapangan.id/diakses 31 Januari 2019). 
yang diterima petani lokal mencapai 57-73 juta dengan selisih pendapatan sosial mencapai 30 juta. Hal ini juga diperkuat dengan nilai EPC dan SRP yang bernilai positif di atas 1.

Kebijakan subsidi input tersebut akan semakin mengurangi tingkat efektivitas dan efisiensinya jika produktivitas bawang merah semakin tinggi. Pada saat produktivitas menjadi tinggi, kebijakan output lebih diperlukan. Selain itu, pembentukan kelembagaan untuk mengakomodir kebutuhan petani, baik input hingga pemasaran, sehingga menghasilkan pembangunan kawasan bawang merah yang berkelanjutan.

Guna memberikan kepastian harga pasar maka pemerintah perlu memerhatikan kondisi harga pasar bawang merah sehingga hasil produksi berjalan dengan baik dan mampu diserap pasar.

\section{UCAPAN TERIMA KASIH}

Terima kasih disampaikan kepada Badan Litbang Pertanian, Kementerian Pertanian yang telah mendanai kegiatan penelitian uji varietas unggul baru dan evaluasi daya saing bawang merah di Maluku dan Kepala Balai Penelitian dan Pengkajian Teknologi Pertanian Maluku atas dukungan moral dan diskusi selama penelitian.

\section{DAFTAR PUSTAKA}

Aldila HF, Fariyanti A, Tinaprilla N. 2017. Daya Saing Bawang Merah di Wilayah Sentra Produksi di Indonesia. Jurnal Manajemen \& Agribisnis. 14(1): 43-53. https://doi.org/10.17358/jma.14.1.43

[BI] Bank Indonesia. 2019. Pusat Informasi Harga Pangan Strategis Nasional. [internet]. [diakses 31 Januari 2019]. Tersedia pada: https:// hargapangan.id/.

[BPS] Badan Pusat statistik. 2016. Provinsi Maluku Dalam Angka. Maluku (ID).

Monke E, Pearson S. 1989. The Policy Analysis Matrix For Agricultural Development. https://web.stanford. edu/group/FRI/indonesia/documents/pambook/pa mbook.pdf.

Nurdi M, Baladina N. 2017. Analisis Keunggulan Komparatif Usaha tani Bawang Merah di Desa Ponjanan Barat, Kecamatan Batumarmar, Kabupaten Pamekasan. Jurnal Ekonomi Pertanian dan Agribisnis. I(1): 44-55. https://doi.org/10. 21776/ub.jepa.2017.001.01.5

Pearson S, Gotsch C. 2004. Applications of the Policy Analysis Matrix in Indonesian Agriculture, Policy
Analysis. https://web.stanford.edu/group/FRI/ indonesia/newregional/newbook.pdf.

Purba R. 2014. Produksi dan Keuntungan Usaha tani Empat Varietas Bawang Merah di Luar Musim (OffSeason) Dikabupaten Serang, Banten. Jurnal Sosial Ekonomi Dan Kebijakan Pertanian. 3(1): 5564.

[Pusdatin] Pusat Data dan Informasi. 2015. Outlook Komoditas Pertanian Subsektor Hortikultura Bawang Merah. Jakarta (ID): Kementan.

[Pusdatin] Pusat Data dan Informasi. 2017. Statistik Pertanian 2017. Jakarta (ID): Kementan.

Rahmadona L, Fariyanti A, Burhanuddin. 2018. Dampak Kebijakan Pemerintah Terhadap Daya Saing Komoditas Bawang Merah di Kabupaten Majalengka. Jurnal Agrosains dan Teknologi. 3(1): 39-46.

Samad MY. 2006. Pengaruh Penanganan Pascapanen Terhadap Mutu Komoditas Hortikultura. Sains dan Teknologi Indonesia. 8(1): 31-36.

Santoso AB, Wahid, Waas ED. 2019. Uji Adaptasi Varietas di lahan Kering untuk Peningkatan Produksi Bawang Merah. Warta Litbang. 41(3): 1214.

Suharyani A, Setiawan B, Mustadjab MM. 2014. Dampak Kebijakan Pemerintah Terhadap Pengembangan Usaha tani Bawang Merah di Kecamatan Bulakamba Kabupaten Brebes. Habitat. 25(1): 16-24.

Suradisastra K. 2008. Strategi Pemberdayaan Kelembagaan Petani. Forum penelitian Agro Ekonomi. 26(2): 82-91. https://doi.org/10.21082/ fae.v26n2.2008.82-91

Susanto AN, Sirappa MP. 2007. Karakteristik dan Ketersediaan Data Sumber Daya Lahan PulauPulau Kecil Untuk Perencanaan Pembangunan Pertanian di Maluku. Jurnal Litbang Pertanian. 26(2): 41-53.

Sutiarso E. 2012. Analisis Daya Saing Agribisnis Bawang Merah di Kabupaten Probolinggo. Agritrop Jurnal Ilmu-ilmu Pertanian. 10(1): 45-54.

Tsurayya S, Kartika L. 2015. Kelembagaan dan Strategi Peningkatan Daya Saing Komoditas Cabai Kabupaten Garut. Jurnal Manajemen dan Agribisnis. 12(1): 1-12. https://doi.org/10.17358/ JMA.12.1.1

Yuniarti AR, Afsari MD. 2016. Profil Komoditas Barang Kebutuhan Pokok dan Barang Penting-Bawang Merah. Jakarta (ID): Kemendag. 